\title{
КЛІНІКО-АНАМНЕСТИЧНІ ПРЕДИКТОРИ ПІСЛЯОПЕРАЦІЙНИХ ГІПОКСИЧНО-ІШЕМІЧНИХ УРАЖЕНЬ ГОЛОВНОГО МОЗКУ ТА АЛГОРИТМ ЇХ ОЦІНКИ В СИСТЕМІ НЕВРОЛОГІЧНОГО СУПРОВОДУ КАРДІОХІРУРГІЧНИХ
} ПАЦІЕНТІВ

\begin{abstract}
Клініко-анамнестичні предиктори післяопераційних гіпоксично-ішемічних уражень головного мозку та алгоритм їх оцінки в системі неврологічного супроводу кардіохірургічних пацієнтів
\end{abstract}

\section{Д. С. Маньковський}

Державна установа «Інститут серця МОЗ України», м. Київ

Резюме. Сучасні технології кардіохірургічних втручань (KXВ) дозволяють значною мірою впливати на структуру смертності, інвалідності та якість життя пацієнтів із критичним перебігом ішемічної хвороби, клапанними пороками серця, кардіоміопатіями. Разом з тим неврологічні ускладнення здатні суттєво впливати на перебіг післяопераційного періоду та нівелювати технічно якісне виконаня КХВ. Останніми роками загальна смертність після КХВ із використанням штучного кровообігу (ШК) характеризуються зменшенням на 20-25\%, тоді як частота гіпоксично-ішемічних уражень (ГІУ) головного мозку (ГМ) практично незмінна $i$, навіть, у старших вікових групах зростає.

Мета дослідження - розробити алгоритм оцінювання ризику гіпоксично-ішемічних уражень головного мозку як компоненти неврологічного супроводу кардіохірургічних пацієнтів.

Матеріали і методи. Дослідження виконано на клінічній базі ДУ «Інститут серця MOЗ України» з використанням первинних матеріалів стосовно кардіохірургічних втручань із застосуванням штучного кровообігу; задіяно дві групи пацієнтів, що сорормовані за методикою копі-пара (за ознаками: вік, стать, вид втручання): в першій ( $n=340$ осіб) - пацієнти з ГІУ ГМ після втручань, у другій (n=340 осіб) - без ГІУ ГМ. У дослідженні використано результати рутинного неврологічного, інструментальних та лабораторних обстежень на етапах оперативного лікування із заповненням спеціальної Карти експертної оцінки неврологічного супроводу пацієнта з кардіохірургічним втручанням.

Результати. При порівняльному міжгруповому аналізі виявлено достовірні $(p<0,05)$ КАФ, виконано їх ранжування за показником загальної інформативності та 10 найбільш інфрормативних включено до алгоритму прогнозування. Наявність достовірної інорормації

(с). С. Маньковський, 2021
Clinical and anamnestic predictors of postoperative hypoxic and ischemic brain lesions and algorithms for their assessment of neurological support of cardiac surgery patients

D. S. Mankovskyy

Heart Institute of Ministry of Health of Ukraine, Kyiv e-mail: serg_shklyar@ukr.net

Summary. Modern technologies of cardiac surgery (CS) can significantly affect the structure of mortality, disability and quality of life of patients with critical ischemic disease, valvular heart disease, cardiomyopathies. In recent years, the overall mortality after CS with the use of artificial circulation (AC) is characterized by a decrease of 20-25\%, while the frequency of hypoxic-ischemic lesions (HIL) of the brain is almost unchanged and, even in older age groups increases.

The aim of the study - to develop an algorithm for assessing the risk of hypoxic-ischemic brain lesions as components of neurological support of cardiac surgery patients.

Materials and Methods. The study was performed on the clinical basis of the State Institution "Heart Institute of the Ministry of Health of Ukraine" with the use of primary materials on cardiac surgery using artificial circulation; involved two groups of patients, formed by the method of copy-pair (by characteristics: age, sex, type of intervention): in the first ( $n=340$ people) - patients with brain HIL after interventions, in the second ( $n=340$ people) - without brain HIL. The study used the results of routine neurological, instrumental and laboratory examinations at the stages of surgical treatment with the completion of a special "Card of expert assessment of neurological support of a patient with cardiac surgery."

Results. The comparative intergroup analysis revealed reliable $(p<0.05) C A F$, their ranking according to the general informativeness was performed and 10 most informative were included in the forecasting algorithm, sequence of the risk assessment procedure and compile the appropriate tabular algorithm, to which, in descending order of informativeness, the most prognostic value features and the corresponding prognostic coefficients are introduced. The forecasting technology is quite simple and to achieve one of the prognostic amounts, which allows you to perform a personalized risk assessment with the simultaneous distri- 
щодо прогностичного значеня клініко-анамнестичних предикторів дозволило обгрунтувати поступовість процедури оцінки ризику та скласти відповідний табличний алгоритм, до якого в порядку зменшуваної інфоормативності, внесені найбільш прогностично цінні ознаки та відповідні прогностичні коефріцієнти. Технологія прогнозування досить проста та (після оцінки наявності/відсутності перелічених в алгоритмі фракторів) передбачає поступове додавання відповідних коефріцієнтів до досягнення однієї із прогностичних сум, що дозволяє виконувати персоніфіковану оцінку ризику з одночасним розподілом (співвідношенням) обстежених осіб до однієї із трьох груп ризику.

Висновки. Вивчено діагностичну цінність та прогностичне значення клініко-анаменстичних предикторів ризику гіпоксично-ішемічних уражень головного мозку, складено прогностичний їх профріль, опрацьовано алгоритм персоніфрікації ризику та виділено три основні прогностично несприятливі синдроми: психоневрологічний (наявність енцефралопатії, артеріальної гіпертензії, закритих черепно-мозкових травм в анамнезі), судинної диссрункції (порушення церебральної ауторегуляції, зниження фрракції викиду лівого шлуночка, інсульт в анамнезі, асиметрія кровонаповнення), серцево-судинних порушень (фрібриляція передсердь, «німий» стеноз сонних артерій, наявність атероматозу висхідної зони аорти).

Ключові слова: гіпоксично-ішемічні ураження головного мозку; предиктори; кардіохірургічні втручання.

\section{ВСТУП}

Сучасні технології кардіохірургічних втручань (KXB) дозволяють значною мірою впливати на структуру смертності, інвалідності та якість життя пацієнтів із критичним перебігом ішемічної хвороби, клапанними пороками серця, кардіоміопатіями [1214]. Разом з тим неврологічні ускладнення здатні суттєво впливати на перебіг післяопераційного періоду та нівелювати технічно якісне виконаня КХB [2, 7]. Останніми роками загальна смертність після КХВ із використанням штучного кровообігу (ШК) характеризується зменшенням на 20-25 \%, тоді як частота гіпоксично-ішемічних уражень (ГІУ) головного мозку (ГМ) практично незмінна і, навіть, у старших вікових групах зростає [7-10]; мозковий інсульт, післяопераційна енцесралопатія та тяжка когнітивна дисфункція у частині випадків залишаються відстроченою проблемою КХВ $[15,16]$, що актуалізує потребу в розробці системи трансопераційного неврологічного супроводу. Задля вирішення цієї проблеми почали застосовувати загрозометричні підходи та методики персоналізації ризику, спрямовані на урахування фракторів, таких, як: атеросклероз аорти $[5,6]$ та брахіоцефальних артерій [18], фрібриляція передсердь [10], супутній цукровий діабет [12], надмірна маса тіла та ожиріння $[10,19]$, куріння та інші $[1$, 4]. Саме тому кардіохірургічні центри експертного bution (correlation) of the surveyed persons to one of the three risk groups.

Conclusions. The diagnostic value and prognostic value of clinical and anamnestic predictors of risk of hypoxicischemic brain lesions were studied, their prognostic profile was compiled, the algorithm of risk personification was developed and three main prognostic adverse syndromes were identified: psychoneurological (encephalopathy, arterial hypertension, closed craniocerebral injuries in the anamnesis), vascular dysfunction (violation of cerebral autoregulation, decreased left ventricular ejection fraction, history of stroke, asymmetry of blood supply), cardiovascular disorders (atrial fibrillation, "silent" carotid artery stenosis, the presence of atheroma of the ascending aorta.

Key words: hypoxic-ischemic brain lesions; predictors; cardiac surgery.

рівня орієнтуються на виконання доопераційного персоналізованого скринінгу при доборі тактики КХВ та подальшої реабілітації пацієнтів [3, 20].

Метою дослідження було розробити алгоритм оцінювання ризику гіпоксично-ішемічних уражень головного мозку як компоненти неврологічного супроводу кардіохірургічних пацієнтів.

\section{МАТЕРІАЛИ I МЕТОДИ}

Дослідження виконано на клінічній базі ДУ «Інститут серця МО3 України» з використанням первинних матеріалів стосовно КХВ із застосуванням ШК за 201-2020 рр.; задіяно дві групи пацієнтів, що сорормовані за методикою копі-пара (за ознаками: вік, стать, вид КХB): в першій ( $\mathrm{n}_{1}=340$ осіб) - пацієнти з ГІУ ГМ після КХВ, в другій $\left(\mathrm{n}_{2}=340\right.$ осіб) - без ГІУ ГМ. У дослідженні використано результати рутинного неврологічного, інструментальних та лабораторних обстежень на етапах КХB із заповненням спеціальної Карти експертної оцінки неврологічного супроводу пацієнта з КХВ. Післяопераційне оцінювання неврологічного статусу, включаючи діагностику можливих ГІУ ГМ, виконано згідно із клінічними протоколами. В процесі виконання дослідження здійснено аналіз КАФ, що найчастіше аналізуються у профрільних публікаціях:
Вісник медичних і біологічних досліджень Bulletin of Medical and Biological Research 
рівень гемоглобіну периферійної крові (КАФ $)$, наявність раніше перенесених ЗЧМТ (КАФ $)$, значення фрракції викиду лівого шлуночка серця - ФВ $\left(К А \Phi_{3}\right)$, наявність «німих» змін ГМ за даними КТ/ MPT $\left(К А \Phi_{4}\right)$, штучна вентиляція легень в анамнезі $\left(К А \Phi_{5}\right)$, наявність АГ (КАФ $\left.{ }_{6}\right)$, стенозу сонних артерій $\left(К А \Phi_{7}\right)$, порушеної церебральної ауторегуляції $\left(К А \Phi_{8}\right)$, наявність енцефралопатії будь-якого генезу $\left(\right.$ КАФ $\left.{ }_{9}\right)$, атероматозу висхідної дуги аорти (КАФ $\left.{ }_{10}\right)$, вертебро-базилярної недостності (КАФ $)$, куріння $\left(К А \Phi_{12}\right)$, хронічної хвороби нирок (КАФ $\left.{ }_{13}\right)$, асиметрії кровонаповнення ГМ (КАФ 14$)$, надмірної маси тіла $\left(К А \Phi_{15}\right)$, варикозної хвороби (КАФ 16 ), цукрового діабету (КАФ 17 ), мозкового інсульту в анамнезі $\left(К А \Phi_{18}\right)$, фрібриляції передсердь (КАФ $\left.{ }_{19}\right)$, аномалій соматотипу (КАФ $\left.{ }_{20}\right)$, попередньо перенесених КХВ $\left(К А \Phi_{21}\right)$, інфекційного ендокардиту $\left(К А \Phi_{22}\right)$, передопераційного рівня оксигенації ГМ (КАФ 23$)$, хронічних захворювань легенів (КАФ $\left.{ }_{24}\right)$, наявність в анамнезі кардіогенного шоку (КАФ 25$)$, проявів легких та середньої тяжкості когнітивних порушень у доопераціному періоді $\left(К А \Phi_{26}\right)$. Застосовано відомі методи медичної статистики та клінічної інфоорматики, зокрема: варіаційну статистику, вірогідний розподіл клінічних та інструментально-лабораторних даних із наступним оцінюванням достовірості результатів порівнння між групами $[11,17]$. У якості базових критеріїв оцінки діагностичної цінності та прогностичного значення КАФ використано показники: частоти, сили впливу фрактора ( $\left.\eta^{2}, \%\right)$, його загальної інфрормативності (I; біт) та відповідні прогностичні коефіцієнти (ПК, пат), що розраховані за відомою стандартною методикою з використанням адаптованої до середовища EXCEL програми [17].

\section{РЕЗУЛЬТАТИ Й ОБГОВОРЕННЯ}

При порівняльному міжгруповому аналізі виявлені достовірні $(p<0,05)$ КАФ, виконано їх ранжування за показником загальної інорормативності та 10 з них (найбільш інформативні; табл. 1) включено до алгоритму прогнозування. Так, з'ясовано, що наявність енцефралопатії (КАФ ) у доопераційному періоді $є$ значимим ( $p<0,001)$ фрактором ризику фрормування ГІУ піля КХВ; так, зареєстровано достовірно більшу частоту КАФ у у групі хворих із ГІУ порівняно з пацієнтами без ГІУ ГМ у післяопераційному періоді (відповідно $(62,4 \pm 2,6) \%$ та $(14,8 \pm 1,9) \%)$. Загальна інорормативність КАФ становить I=2,324 біт, тоді як сила впливу фрактора $-\eta^{2}=24,0 \%$, а прогностичні коеоріцієнти: за наявності КАФ - ПК відсутності ПК=-3,5 пат.

Виявлено, що наявність АГ (КАФ $)$ у доопераційному періоді $€$ значимим ( $<<0,001)$ фактором ризику фрормування ГІУ після КХВ; зареєстровано достовірно більшу частоту АГ у групі хворих із ГІУ порівняно 3 пацієнтами без ГІУ ГМ (відповідно $(57,9 \pm 2,7) \%$ та $(22,7 \pm 2,3) \%)$. Загальна інфрормативність цієї клініко-анамнестичної ознаки становить

Таблиця 1. Алгоритм персоніфікації доопераційного ризику гіпоксично-ішемічних уражень головного мозку при виконанні кардіохірургічних втручань зі штучного кровообігу

\begin{tabular}{|c|c|c|c|}
\hline \multirow{2}{*}{ І, біт } & \multirow{2}{*}{ Клініко-анамнестичні маркери ризику } & \multicolumn{2}{|c|}{ Прогностичний коесріцієнт } \\
\hline & & критерій & ПК, пат \\
\hline \multirow[t]{2}{*}{2,324} & \multirow[t]{2}{*}{ КАФ : наявність енцефралопатії } & так & $+6,2$ \\
\hline & & $\mathrm{Hi}$ & $-3,5$ \\
\hline \multirow[t]{2}{*}{1,177} & \multirow[t]{2}{*}{ КАФ $:$ : наявність артеріальної гіпертензії } & так & $+4,1$ \\
\hline & & $\mathrm{Hi}$ & $-2,6$ \\
\hline \multirow[t]{2}{*}{1,169} & \multirow{2}{*}{ КАФ : верифрікована ЗЧМТ, в анамнезі } & так & $+5,2$ \\
\hline & & ні & $-2,0$ \\
\hline \multirow[t]{2}{*}{1,054} & \multirow[t]{2}{*}{ КАФ ${ }_{26}:$ нетяжкі когнітивні порушення } & так & $+3,3$ \\
\hline & & $\mathrm{Hi}$ & $-2,8$ \\
\hline \multirow[t]{2}{*}{0,713} & \multirow{2}{*}{ КАФ : порушення церебральної ауторегуляції } & так & $+4,9$ \\
\hline & & $\mathrm{Hi}$ & $-1,3$ \\
\hline \multirow[t]{2}{*}{0,688} & \multirow[t]{2}{*}{ КАФ ${ }_{17}:$ цукровий діабет } & так & $+4,8$ \\
\hline & & $\mathrm{Hi}$ & $-1,3$ \\
\hline \multirow[t]{3}{*}{0,618} & \multirow[t]{3}{*}{ КАФ : фрракція викиду лівого шлуночка, \% } & $<30$ & $+4,1$ \\
\hline & & $30-40$ & $+1,6$ \\
\hline & & $>40$ & $-1,9$ \\
\hline \multirow[t]{2}{*}{0,608} & \multirow{2}{*}{ КАФ $:$ : «німі» зміни ГМ: нейровізуалізація } & так & $+4,4$ \\
\hline & & $\mathrm{Hi}$ & $-1,2$ \\
\hline \multirow[t]{3}{*}{0,524} & \multirow[t]{3}{*}{ КАФ 1 : рівень гемоглобіну периферійній крові } & норма & $-1,6$ \\
\hline & & $-10 \%$ & $+1,4$ \\
\hline & & $<-10 \%$ & $+4,5$ \\
\hline \multirow[t]{2}{*}{0,490} & \multirow[t]{2}{*}{ КАФ 18 : інсульт в анамнезі } & так & $+6,7$ \\
\hline & & $\mathrm{Hi}$ & $-0,6$ \\
\hline
\end{tabular}


I=1,177 біт, тоді як сила впливу фрактора $-\eta^{2}=13,0$ \%, а ПК: за наявності АГ $-П \mathrm{~K}^{+}=+4,1$ пат, за відсутності ПК =-2,6 пат. Наявність ЗЧМТ в анамнезі $\left(\mathrm{KA \Phi}_{2}\right)$ зареєстровано достовірно ( $\left.<<0,001\right)$ та втричі частіше серед хворих із ГІУ, ніж серед пацієнтів без

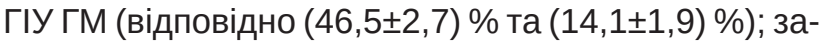
гальна інформативність КАФ $-\mathrm{I=1,169}$ біт, тоді як сила впливу фрактора $-\eta^{2}=12,0 \%$, а прогностичні коефріцієнти: за наявності ЗЧМТ - ПК=5,5 пат, за відсутності ПК=2,0 пат.

У доопераційному періоді наявність не тяжких когнітивних порушень (КАФ 26 ) діагностовано достовірно ( $p<0,001)$ та вдвічі частіше серед хворих із ГІУ, ніж серед пацієнтів без ГІУ (відповідно $(63,1 \pm 2,6) \%$ та $(29,1 \pm 2,5) \%$; загальна інфрормативність цієї клініко-анамнестичної ознаки - I=1,054 біт, тоді як сила впливу фрактора на розбіжність двох груп - $\eta^{2}=12,0$ \%, а прогностичні коефріцієнти: за наявності ЗЧМТ ПК $=+3,3$ пат, за відсутності - ПК-2,8 пат.

3'ясовано, що наявність порушеної церебральної ауторегуляції (КАФ $)$ у доопераційному періоді є значимим ( $p<0,001)$ фактором ризику ГІУ після КХВ; так, зареєстровано достовірно більшу частоту АГ в групі хворих із ГІУ, порівняно з пацієнтами без ГІУ ГМ у післяопераційному періоді (відповідно $(33,8 \pm 2,6) \%$ та $(10,9 \pm 1,7) \%)$. Загальна інорормативність цієї клініко-анамнестичної ознаки становить I=0,713 біт, тоді як сила впливу фрактора на розбіжність двох груп - $\eta^{2}=7,0 \%$, а прогностичні коефріцієнти: за наявності порушеної церебральної ауторегуляції - ПК $=+4,9$ пат, за їх відсутності ПК=-1,3 пат.

Встановлено, що показник фрракції викиду лівого шлуночка $\left(\mathrm{KA \Phi}_{3}\right)$ у доопераційному періоді $€$ значимим ( $<<0,001)$ фрактором ризику фрормування ГІУ після КХВ; так, зареєстровано достовірно більшу частоту осіб із ФВ лш меншою за 30,0 \% в групі хворих з ГІУ, порівняно з пацієнтами без ГІУ ГМ у післяопераційному періоді (відповідно $(23,7 \pm 2,3) \%$ та $(9,1 \pm 1,6) \%$ осіб). Окрім того, аналогічно, серед пацієнтів із ГІУ достовірно більше було осіб з ФВ у межах $(30,0 \pm 40,0) \%$. Разом з тим серед пацієнтів без ГІУ, порівняно з хворими з ГІУ, достовірно ( $<<0,001)$ пераважали хворі з ФВ лш понад 40,0\% (відповідно $(69,1 \pm 2,5) \%$ та $(44,6 \pm 2,7) \%$ осіб). Загальна інфрормативність цієї ознаки становить I=0,618 біт, тоді як сила впливу фрактора на розбіжність двох груп була $\eta^{2}=7,0$ \%, а прогностичні коефріцієнти: за наявності зниженої ФВ лш менше 30,0 \% становить $П \mathrm{~K}^{+}=+4,1$ пат, за наявності ФВ 40,0 \% становить ПК=-1,9 пат (рис.).

Наявність ЦД в анамнезі (КАФ 17 ) зареєстровано достовірно ( $p<0,001)$ та втричі частіше серед хворих із ГІУ, ніж серед пацієнтів без ГІУ (відповідно $(34,2 \pm 2,6) \%$ та $(11,5 \pm 1,7) \%)$; загальна інфрормативність цієї клініко-анамнестичної ознаки - I=0,688 біт, тоді як сила впливу фрактора на розбіжність двох груп становить $\eta^{2}=7,0 \%$, а прогностичні коефріцієнти: за наявності ЦД - ПК=+4,8 пат, за відсутності ПК $\mathrm{K}^{+}=-1,3$ пат.

При інструментальному плановому обстеженні (КТ, МРТ) «німі» зміни ГМ (КАФ $)$ діагностовано у доопераційному періоді значно ( $p<0,001)$ частіше серед осіб, у яких в післяопераційному періоді КХВ виявлено ГІУ, ніж серед пацієнтів без значимих ГІУ (відповідно $(33,5 \pm 2,6) \%$ та $(12,1 \pm 1,8) \%$ осіб). Загальна інформативність цієї ознаки становить I=0,608 біт, тоді як сила впливу фрактора на розбіж-

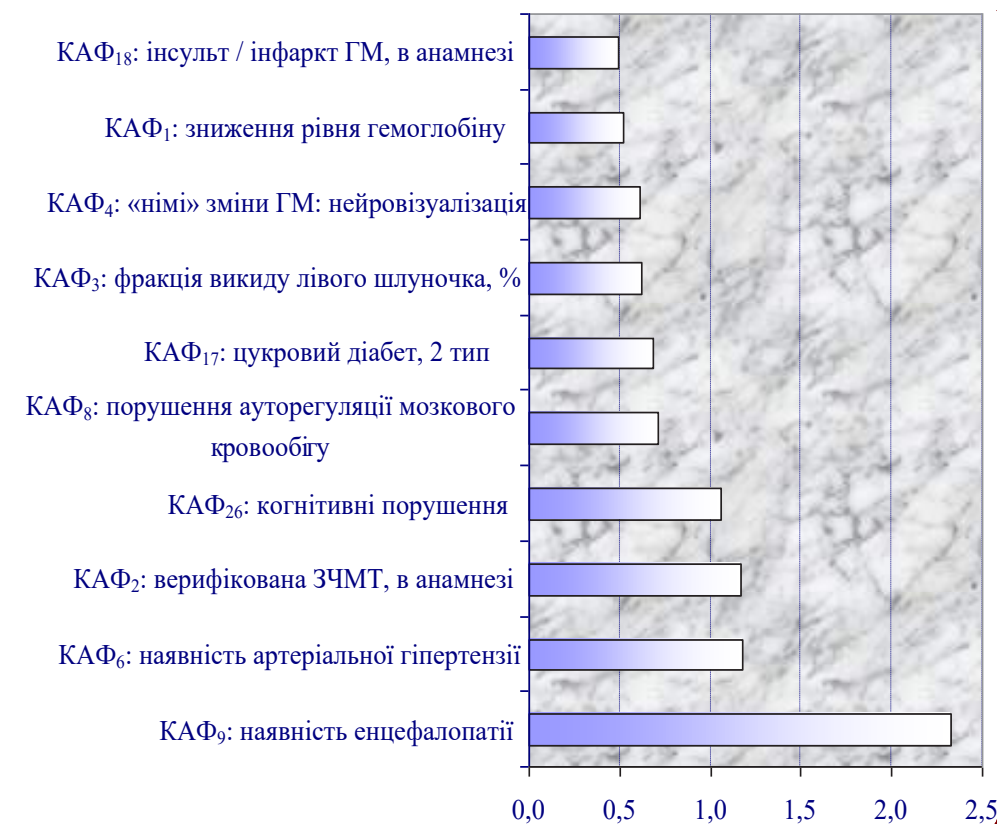

Рис. Діагностичний просріль (клінічна інорормативність, біт) достовірних (p<0,001) та високоінформативних (I>0,500 біт) клініко-анамнестичних предикторів гіпоксично-ішемічних уражень головного мозку. 
ність двох груп складає $\eta^{2}=6,0 \%$, а прогностичні коефіцієнти: за наявності КАФ становить ПК +4,4 пат, за відсутності - ПК=-1,2 пат.

При цьому анамнестична вказівка (КАФ 18 на перенесений раніше інсульт (інфраркт ГМ) також виявилася інорормативною: значно $(p<0,001)$ частіше серед осіб, у яких в післяопераційному періоді КХB виявлено ГІУ, ніж серед пацієнтів без значимих ГІУ (відповідно $(16,8 \pm 2,0) \%$ та $(3,5 \pm 1,0) \%$ осіб). Загальна інформативність цієї ознаки становить I=0,490 біт, тоді як сила впливу фрактора на розбіжність двох груп становить $\eta^{2}=5,0 \%$, а прогностичні коеоріцієнти: за наявності КАФ ${ }_{18}$ становить $П \mathrm{~K}^{+}=+6,7$ пат, за відсутності - ПК=-0,6 пат.

Досить цікавим виявилась закономірність зростання ризику ГІУ ГМ залежно від рівня гемоглобіну периорерійної крові в доопераційному періоді. Так, у разі його відповідності референтним значенням (в групі з ГІУ - у $(47,4 \pm 2,7) \%$, у групі без ГІУ - серед $(69,4 \pm 2,5) \%$ осіб, p<0,001) маємо ПК=-1,6 пат. Тоді як ризик формування ГІУ зростає при зниженні рівнів гемоглобіну. Загальна інформативність цієї ознаки становить $I=0,548$ біт, тоді як сила впливу фрактора на розбіжність двох груп становить $\eta^{2}=6,0 \%$.

Таким чином, наявність достовірної інфрормації щодо прогностичного значеня КАФ дозволило обґрунтувати послідовність процедури персоніфрікованої оцінки ризику ГІУ ГМ та скласти відповідний алгоритм (табл. 1). До таблиці в порядку зменшуваної інфрормативності внесені найбільш прогностично цінні ознаки та відповідні прогностичні коеоріцієнти (ПК). Технологія прогнозування досить проста та (після оцінки наявності/відсутності перелічених в алгоритмі КАФ) передбачає послідовне додавання відповідних коефріцієнтів до досягнення однієї із прогностичних сум (ПС). Це дозволяє виконувати персоніфіковану оцінку ризику з одночасним розпо- ділом (співвідношенням) обстежених осіб до однієї із трьох груп ризику (табл. 2).

Необхідно також зазначити, що добір ПС передбачає попереднє визначення помилок першого (альфра) та другого (бета) роду за спеціальною таблицею [11], що гарантує відповідний рівень точності при застосуванні алгоритму.

Зазначимо, що у конкретного пацієнта поєднання тих чи інших КАФ та, відповідно, оцінювання ризику ГІУ ГМ необхідно виконувати з використанням опрацьованого алгоритму. Це дозволяє відмовитись від громіздких та затратних методів обстеження, «скоротити» процес прогнозування та, одночасно, враховувати найбільш прогностично цінні ознаки.

Приклад застосування алгоритму. Пацієнт П., 57 років, на етапі планування КХВ із використання ШК, при аналізі історії хвороби та за результатами клініко-анамнестичного обстеження виявлено, що у нього відсутні прояви енцефалопатії (ПК=3,5), має місце наявність артеріальної гіпертензії (ПК=+4,1; прогностична сума (ПС) становить ПС=-3,5+4,1=+0,6 пат), в анамнезі у пацієнта ЗЧМТ (ПК=+5,2; ПС=0,6+5,2=5,8 пат), виявлені легкі когнітивні порушення (ПК=+3,3: ПС=5,8+3,3=9,1 пат) та порушення церебральної ауторегуляції (ПК=+4,9: ПС=9,1+4,9=14 пат), враховано наявність у пацієнта цукрового діабету (ПК=+4,8: ПС=14,0+4,8= 18,8 пат). Процес прогнозування призупинено, оскільки досягнуто прогностично значимої суми (ПС>+17,0), що дозволяє з вірогідністю не менше 97,0 \% прогнозувати прояви ГІУ ГМ у разі виконання КХВ із використанням ШК.

Перспективи подальших досліджень полягають у вивченні прогностичного потенціалу КАФ стосовно оцінювання персоніфрікованого ризику окремих нозологічно окреслених проявів ГІУ в післяопераційному періоді КХВ зі шк: інсульту, енцефалопатії, тяжкої когнітивної дисорункції.

Таблиця 2. Візуально-аналогова шкала оцінки персоналізованого результату прогнозування гіпоксично-ішемічних уражень головного мозку

\begin{tabular}{l|l|l}
\hline \multicolumn{3}{c}{ Шкала оцінки персоналізованого результату прогнозування } \\
\hline$\Pi C_{\text {min }} \leq-11,0$ & $-11,0>П C<+17,0$ & $\Pi C_{\max } \geq+17,0$ \\
низький ризик ГІУ ГМ & невизначений ризик & високий ризик ГІУ ГМ \\
\hline
\end{tabular}

\section{ВИСНОВКИ}

Вивчено діагностичну цінність та прогностичне значення КАФ у фромуванні ризику ГІУ ГМ серед пацієнтів із КХВ зі ШК, фрактори проранжовані, опрацьовано алгоритм персонісрікації ризику та виділено три основні прогностично несприятливі синдроми: психоневрологічний (наявність енце- фралопатії, АГ, ЗчМТ в анамнезі), судинної дисорункції (порушення церебральної ауторегуляції, зниження ФВ асиметрія кровонаповнення ГМ), серцево-судинних порушень (фрібриляція передсердь, «німий» стеноз сонних артерій, наявність атероматозу висхідної зони аорти). 


\section{СПИСОК ЛІТЕРАТУРИ}

1. How to recognize and treat metabolic encephalopathy in neurology intensive care unit / I. I. Berisavac, D. R. Jovanovic, V. V. Padjen [et al.] // Neurol. India. - 2017. - No. 65 (1). - P. 123-128.

2. Дьогтяр В. В. Профрілактика неврологічних ускладнень при хірургії торако-абдомінального відділу аорти / В. В. Дьогтяр, Н. О. Чанглі // Вісник серцево-судинної хіpypriï. - 2018. - № 3. - С. 68-70.

3. Demikhov O. Actual aspects of public health policy formation on the example of Ukraine / O. Demikhov, I. Dehtyarova, N. Demikhova // Bangladesh Journal of Medical Science. - 2020. - No. 19 (3). - P. 358-364.

4. Arterial hypertension prevention as an actual medical and social problem / O. Demikhov, I. Dehtyarova, O. Rud [et al.] // Bangladesh Journal of Medical Science. - 2020. Vol. 19 (4). - P. 722-729.

5. Dynamic of endothelial dysfunction factors during treatment in renal hypertensive patients / O. Demikhov, N. Demikhova, M. Zakharchenko [et al.] // Atherosclerosis. - 2019. - P. 287.

6. Demikhov O. Awareness study of patients with arterial hypertension / O. Demikhov, S. Nei, N. Demikhova // European Journal of Heart Failure. Oxford: edition European Society of Cardiology. - 2019. - No. 21 (1). - P. 570.

7. Feigin V. L. Anthology of stroke epidemiology in the 20th and 21st centuries: Assessing the past, the present, and envisioning the future / V. L. Feigin // International Journal of Stroke. - 2019. - No. 14 (3). - P. 223-237.

8. Feigin V. L. Global burden of stroke and risk factors in 188 countries, during 1990-2013: a systematic analysis for the Global burden of disease study 2013 / V. L. Feigin, G. A. Roth, M. Naghavi // Lancet Neurol. - 2016. - No. 15. - P. 913-924.

9. Preterm hypoxic-ischemic encephalopathy / K. R. Gopagondanahalli, J. Li, M. C. Fahey [et al.] // Front Pediatr. - 2016. - No. 4. - P. 114.

10. Hahne K. Atrial fibrillation and silent stroke: links, risks, and challenges / K. Hahne, G. Monning, A. Samol // Vascular Health Risk Management. - 2016. - Vol. 12. - P. 65-74.

\section{REFERENCES}

1. Berisavac II, Jovanović DR, Padjen VV, Ercegovac MD, Stanarčević PD, Budimkić-Stefanović MS, Radović $\mathrm{MM}$, et al. How to recognize and treat metabolic encephalopathy in neurology intensive care unit. Neurol India. 2017;65(1): 123-8.

2. Dyogtyar VV, Changli NO. [Prevention of neurological complications in surgery of the thoraco-abdominal aorta]. Visnyk sertsevo-sudynnoi khirurhii. 2018;3: 68-70. Ukrainian.

3. Demikhov O, Dehtyarova I, Demikhova N. Actual aspects of public health policy formation on the example of Ukraine. Bangladesh Journal of Medical Science. 2020;19(3): 358-64.

4. Demikhov O, Dehtyarova I, Rud O, Khotyeev Y, Kuts L, Cherkashyna L, Demikhova N, et al. Arterial hypertension prevention as an actual medical and social problem. Bangladesh Journal of Medical Science. 2020;19(4): 722-9.

5. Demikhov O, Demikhova N, Zakharchenko M, Bumeister L. Dynamic of endothelial dysfunction factors during treatment in renal hypertensive patients. Atherosclerosis. 2019; 287.
11. Гублер Е. В. Клиническая патоинорорматика в медицине и педиатрии / Е. В. Гублер. - Медицина, 1992. - C. 211.

12. Risk factors for delirium after cardiac surgery: an historical cohort study outlining the influence of cardiopulmonary bypass / J. B. O'Neal, F. T. Billings, X. Liu [et al.] // Can. J. Anaesth. - 2017. - No. 64 (11). - P. 1129-1137.

13. Guidelines for the early management of patients with acute ischemic stroke: a guideline for healthcare professionals from the American Heart Association / E. C. Jauch, J. L. Saver, H. P. Adams [et al.] // Stroke. - 2013. - No. 44 (3). - P. 870-947.

14. Stroke: a global response is needed / W. Johnson, O. Onuma, M. Owolabi [et al.] // World Health Organ. 2016. - No. 94. - P. 634-634a.

15. Atrial fibrillation and mechanisms of stroke: Time for a new model / H. Kamel, P. M. Okin, M. S. Elkind [et al.] // Stroke. - 2016. - No. 47. - P. 895-900.

16. Risk factors for perioperative ischemic stroke in cardiac surgery / M. A. Costa, M. F Gauer, R. Z. Gomes [et al.] // Rev. Bras. Cir. Cardiovasc. - 2015. - No. 30 (3). P. 365-372.

17. Реброва О. Ю. Статистический анализ медицинских данных. Применение пакета прикладных программ Statistica / О. Ю. Реброва // MedyaSfera. - 2002. - 312 p.

18. Трусранов Е. А. Цереброваскулярные заболевания: заболеваемость, смертность, фракторы риска, диагностика и лечение / Е. А. Труфанов, Н.К.Свиридова, Т. Р. Парнякова // Східно-європейський неврологічний журнал. - 2016. - № 4 (10). - С. 17-20.

19. Current practice and future directions in the diagnosis and acute treatment of ischaemic stroke / C. Zerna, G. Thomalla, B. C. Campbell [et al.] // The Lancet. - 2018. No. 392 (10154). - P. 1247-1256.

20. Зозуля І. С. Деякі напрямки поліпшення надання медичної допомоги при мозковому інсульті / І. С. Зозуля, А. І. Зозуля, А. О. Волосовець // Український вісник психоневрології. - 2017. - Т. 25, вип. 1. - С. 84-85.

6. Demikhov O, Nei S, Demikhova N. Awareness study of patients with arterial hypertension. European Journal of Heart Failure. Oxford: edition European Society of Cardiology. 2019; 21(1): 570.

7. Feigin VL. Anthology of stroke epidemiology in the 20th and 21st centuries: Assessing the past, the present, and envisioning the future. International Journal of Stroke. 2019;14(3): 223-37.

8. Feigin VL, Roth GA, Naghavi M. Global burden of stroke and risk factors in 188 countries, during 1990-2013: a systematic analysis for the Global burden of disease study 2013. Lancet Neurol. 2016;15: 913-24.

9. Gopagondanahalli KR, Li J, Fahey MC, Hunt RW, Jenkin G, Miller SL, Malhotra A. Preterm hypoxic-ischemic encephalopathy. Front Pediatr. 2016;4: 114.

10. Hahne K, Monning G, Samol A. Atrial fibrillation and silent stroke: links, risks, and challenges. Vascular Health Risk Management. 2016;12: 65-74.

11. Gubler EV. [Clinical pathoinformatics in medicine and pediatrics]. Meditsina. 1992. Russian. 
12. O'Neal JB, Billings FT, Liu X, Shotwell MS, Liang Y, Shah AS, Ehrenfeld JM, et al. Risk factors for delirium after cardiac surgery: an historical cohort study outlining the influence of cardiopulmonary bypass. Can J Anaesth. 2017;64(11): 1129-37.

13. Jauch EC, Saver JL, Adams HP, Bruno A, Connors JJ, Demaerschalk BM, Khatri P, et al. Guidelines for the early management of patients with acute ischemic stroke: a guideline for healthcare professionals from the American Heart Association. Stroke. 2013;44(3): 870-947.

14. Johnson W, Onuma O, Owolabi M, Sachdev S. Stroke: A global response is needed. World Health Organ. 2016;94: 634-4a.

15. Kamel H, Okin PM, Elkind MS, ladecola C. Atrial fibrillation and mechanisms of stroke: Time for a new model. Stroke. 2016;47: 895-900.

16. Costa MA, Gauer MF, Gomes RZ, Schafranski MD.
Risk factors for perioperative ischemic stroke in cardiac surgery. Rev Bras Cir Cardiovasc. 2015;30(3): 365-72.

17. Rebrova OY. [Statistical analysis of medical data. Application of the Statistica software package]. MedyaSfera. 2002; 312. Russian.

18. Trufanov EA, Sviridova NK, Parnyakova TR. [Cerebrovascular diseases: morbidity, mortality, risk factors, diagnosis and treatmen]. Skhidno-yevropeiskyi nevrolohichnyi zhurnal. 2016;4(10): 17-20. Russian.

19. Zerna C, Thomalla G, Campbell BCV, Rha JH, Hill MD. Current practice and future directions in the diagnosis and acute treatment of ischaemic. The Lancet. 2018;392(10154): 1247-56.

20. Zozulya IS, Zozulya AL, Volosovets AO. [Some directions of improving the provision of medical care for stroke]. Ukrainskyi visnyk psykhonevrolohii. 2017;25(1): 845. Ukrainian. 